

\title{
Economic Analysis of Brown Sugar Processing in Nagari Bukik Batabuah Agam District
}

\author{
Alvindo Dermawan*, Nofialdi, and Yusmarni \\ Departement of Social Economics, Faculty of Agriculture, Andalas University, Padang, Indonesia
}

\begin{abstract}
The aims of this study are to describe the economy of households that run brown sugar processing and to identify the factors affecting the decision of households in producing brown sugar and household consumption. There are 528 households in total that run traditional brown sugar procesing in Nagari Bukik Batabuah. 30 households were chosen randomly as the reseach sample using the simple random sampling method. The research shows that work time allocation of the households was higher for processing brown sugar than other activities. Consequently, the income of households derived from brown sugar processing was also higher than other activities which was $\mathrm{Rp} 2.581 .667$. Generally, $82 \%$ of household income derives from brown sugar processing. Moreover, the households spent most of their income on food and there was no remaining income to save and invest. Furthermore, factors that affect the decision of households in producing brown sugar were: availability of raw materials, brown sugar price and needs of the households. Meanwhile the factors that affect the consumption of households were: household income, the number of family members, and the number of family members that are still at school.
\end{abstract}

Keywords: consumption, household economy, production

Received 25 January 2019 | Revised 05 April 2019 | Accepted 13 April 2014

\section{Introduction}

Sugar cane plant is one of the potential plantation crops that have a high economic value in West Sumatra. There is an increse of sugar cane production in West Sumatra every year which was 14,908 tons in $2010,14,915$ tons in $2011,14,921$ tons in 2012, and 14,923 tons in 2013. In some regions in West Sumatra, sugar cane is processed into brown sugar (saka). Brown sugar is widely used for household consumption such as for sweeteners and aroma and color enhancers. Brown sugar (saka) is also used as raw material in small industries, both for food and beverages. Usually, the brown sugar is produced on a home industry scale [1].

Sugar cane in West Sumatera is mainly produced from the Agam District with a production area of 3,975 ha. Meanwhile the subdistrict with the highest production of sugar cane in Agam is the Canduang Subdistrict with a total production of 2,815.75 tons in 2013 [2]. One of the regions that

\footnotetext{
*Corresponding author at: Agribusiness Study Program, Faculty of Agriculture, Universitas Andalas, Limau Manis 25163, Indonesia

E-mail address: dermawan_alvindo@yahoo.com
} 
process sugar cane into brown sugar (saka) in the Canduang Subdistrict is Nagari Bukik Batabuah. There are around $80 \%$ of the total population of Nagari Bukik Batabuah that depend on traditionally processed sugar cane [3].

The procesing of sugar cane into brown sugar was carried out in huts located near the plantation. Sugar cane was processed traditionally using a traditional refinery driven by a buffalo. A household could carry out processing activities twice a day and each runs approximately 5 hours. One time processing activities consumes $80-100$ sticks of sugar cane and produces $35-50 \mathrm{~kg}$ of brown sugar. Afterwards, the households sell their brown sugar to wholesalers. Brown sugar processing is the main income for $80 \%$ households in Nagari Bukik Batabuah [3]

The length of time needed in processing of brown sugar causes households to allocate more working time in order to earn income. Access to public transportation is also limited, which can affect the marketing process of brown sugar. The households cannot sell their production directly to the market, therefore they have to wait for wholesalers to purchase their brown sugar. This condition could lead to uncertain income of the households.

The Analysis of the contribution of added value received by farmers was very low compared to other business actors [4]. Farmers' perceptions were very low in brown sugar so that farmers did not carry out their businesses wholeheartedly [5]. The low value added received by brown sugar farmers and the low perceptions of farmers on their business will affect the economic condition of households because the processing of brown sugar is the main work of most of the farmers around. The objectives of this research are describe the economy of households that run brown sugar processing in Kenagarian Bukit Batabuah, Canduang District, Agam Regency, West Sumatra and identify the factors affecting the decision of households in producing brown sugar and household consumption in Kenagarian Bukit Batabuah, Canduang District, Agam Regency, West Sumatra.

\section{Research Methods}

This research was conducted in Nagari Bukik Batabuah, Canduang subdistrict, Agam Regency. This research utilizes the survey method and data were gathered from 30 households that traditionally run brown sugar processing, sampling method used random sampling from 528 households. 30 is a minimum sample in quantitative research [6]. In general, the method used in this study was a combination of qualitative and quantitative method [7]. The qualitative method was used to answer the first research objective. Meanwhile, the second research objective was analyzed quantitatively using the following models: 


\subsection{Work Time Allocation}

$$
\text { CTKtot }=\mathrm{CTKKK}+\mathrm{CTKDK}
$$

Where:

CTKtot : Total work time allocation (hours/month)

CTKKK: Work time allocation of the head of the household (hours/month)

CTKAK: Work time allocation of family members (hours/month)

\subsection{Household Income}

$$
\mathrm{Y}=\mathrm{PD}+\mathrm{PS}
$$

Where:

Y : Total household income (IDR/Month)

PD : Income from brown sugar processing (IDR /Month)

PS : Income from side jobs (IDR /Month)

$$
\mathrm{PD}=(\mathrm{H} . \mathrm{Q})-\mathrm{B}
$$

Where:

PD : Income from brown sugar processing (IDR/Month)

$\mathrm{H}$ : Price of brown sugar (IDR/Kg)

Q : Amount of brown sugar production (IDR/Month)

B : Production cost (IDR/Month)

$$
\mathrm{PS}=\mathrm{UPS}
$$

Where:

PS : Income from side jobs (IDR/Month)

UPS : Wages from side jobs (IDR/Month)

\subsection{Household Consumption}

$$
\begin{gathered}
\mathrm{C}=\mathrm{C} 1+\mathrm{C} 2 \\
\mathrm{C} 1=\mathrm{C} 11+\mathrm{C} 12+\mathrm{C} 13+\mathrm{C} 14+\mathrm{C} 15 \\
\mathrm{C} 2=\mathrm{C} 21+\mathrm{C} 22+\mathrm{C} 23+\mathrm{C} 24+\mathrm{C} 25+\mathrm{C} 26
\end{gathered}
$$


Where:

C : Total household expenditure (IDR/Month)

C1 : Consumption for food (IDR/Month)

C2 : Consumption for non-food (IDR/Month)

C11 : Grains, tubers (IDR/Month)

C12 : Side dishes, vegetables and fruit (IDR/Month)

C13 : Beverage ingredients (coffee, tea, sugar), finished food (IDR/Month)

C14 : Cooking oil, spices (IDR/Month)

C15 : Tobacco/cigarettes (IDR/Month)

C21 : Housing and household facilities (IDR/Month)

C22 : Education (IDR/Month)

C23 : Clothes (IDR/Month)

C24 : Events (IDR/Month)

C25 : Health (IDR/Month)

C26 : Recreation, tax, contribution (IDR/Month)

Moreover, to identify the factors affecting the decision of households in brown sugar production and consumption, the data were analyzed using frequency distribution of statistic descriptive analysis.

\section{Results and Discussion}

\subsection{Respondent Identity}

The highest age of respondents is 15-55 years as many as 19 people or 63 percent and the rest are large age groups of 55 years as many as 11 or 37 percent. the respondent's last education was as many as 28 primary schools or the remaining 93 percent or 7 percent had junior high school education. The longest experience in processing brown sugar is 25-39 years as many as 16 respondents or 53 percent, while the shortest experience is $15-24$ years as many as 5 people or 17 percent.

\subsection{Overview of the Households that Process Brown Sugar}

The general description of the economy of households that process brown sugar in Kenagarian Bukik Batabuah can be seen from the work time allocation, total household income, total household consumption, investment and household savings. 


\subsubsection{Working time allocation}

This study measures working time allocations in brown sugar processing and outside brown sugar processing for the head of the household (husband) and family members (wife and children).

Table 1. Average Work Time Allocation of the Households

\begin{tabular}{lcccccc}
\hline \multirow{2}{*}{ Activities } & \multicolumn{5}{c}{ Working Time Allocation } \\
\cline { 2 - 7 } & $\begin{array}{c}\text { Husband } \\
\text { (Hour/month) }\end{array}$ & $\mathbf{( \% )}$ & $\begin{array}{c}\text { Wife } \\
\text { (Hour/month) }\end{array}$ & $\mathbf{( \% )}$ & $\begin{array}{c}\text { Children } \\
\text { (Hour/month) }\end{array}$ & $\mathbf{( \% )}$ \\
\hline $\begin{array}{l}\text { Brown sugar } \\
\text { processing }\end{array}$ & 84 & 55 & 57 & 58 & 43 & 47 \\
$\begin{array}{l}\text { Outside brown sugar } \\
\text { processing }\end{array}$ & 69 & 45 & 42 & 42 & 48 & 53 \\
Total & 153 & 100 & 99 & 100 & 91 & 100 \\
\hline
\end{tabular}

Table 1 shows that the working time allocation is higher on brown sugar processing than outside of it. This condition indicates that brown sugar processing is the main profession for households in the research area. The side jobs of the households consists of collecting wood as fuel in processing of brown sugar, picking grass for cattles and other activities such as farming (parakmudo), sewing, and trading.

Processing activities usually start from $06.00 \mathrm{am}$ or at the most $07.00 \mathrm{am}$ until $17.00 \mathrm{pm}$. Table 1 shows that the husband has the longest working time on brown sugar processing. The duty of the husband on processing of brown sugar includes choosing the proper sugar cane that can be refined, cleaning it, and cooking it until it turns to caramel (nira). Meanwhile, the wife converts the caramel into brown sugar, and the children prepare wood as fuel while the cooking process is ongoing. Moreover, brown sugar processing is carried out for 2-3 days a week, so the household can do side jobs on vacant days.

\subsubsection{Household income}

This study measures the total household income earned from brown sugar processing and side jobs.

Table 2. Average Household Income Based on Income Sources

\begin{tabular}{lcc}
\hline \multirow{2}{*}{ Source Income Average } & \multicolumn{2}{c}{ Average Household Income } \\
\cline { 2 - 3 } & IDR/Month & Percent (\%) \\
\hline Brown sugar processing & 2.581 .667 & 82 \\
Side jobs & 578.235 & 18 \\
\hline
\end{tabular}

Table 2 shows that $82 \%$ of household income comes from brown sugar processing, and the rest from side jobs. This indicates that brown sugar processing is the main source of income for households in the research site. 
Households carry out the brown sugar processing for only 2-3 days a week which are Saturday, Sunday and Monday, which takes around 11 hours a day. Meanwhile the other days are spent on activities outside the processing of brown sugar. Activities outside of brown sugar processing usually start at 9:00 a.m. until 3:00 p.m.

\subsubsection{Consumption}

This study measures the total consumption of the households that consists of food and non food consumptions.

Table 3. Household Consumption Based on Income

\begin{tabular}{|c|c|c|c|c|}
\hline \multirow{2}{*}{$\begin{array}{c}\text { Income } \\
\text { (Rp/month) }\end{array}$} & \multirow{2}{*}{$\begin{array}{l}\text { Number of } \\
\text { Households }\end{array}$} & \multicolumn{2}{|c|}{$\begin{array}{c}\text { Consumption } \\
\text { (IDR/month) }\end{array}$} & \multirow{2}{*}{$\begin{array}{c}\text { Total } \\
\text { Consumption } \\
\text { (IDR/month) }\end{array}$} \\
\hline & & Food & Non Food & \\
\hline \multirow{2}{*}{$<1.800 .000$} & 2 & 1.522 .500 & 337.500 & 1.860 .000 \\
\hline & $(7 \%)$ & $(49 \%)$ & $(36 \%)$ & $(46 \%)$ \\
\hline \multirow{2}{*}{$\geq 1.800 .000$} & 28 & 1.590 .179 & 590.911 & 2.181 .089 \\
\hline & $(93 \%)$ & $(51 \%)$ & $(64 \%)$ & $(54 \%)$ \\
\hline
\end{tabular}

Table 3 indicates that the higher the income, the higher the household consumption. The interviews with the households find that all households spend their income for food. However, some households spend their income on non-food consumption such as clothing, parties, and recreation. Moreover, the research also finds that the higher the number of family members, the higher the household consumption.

\subsubsection{Investation and saving}

The investment intended in this study is the amount of resources utilized by households to develop their brown sugar processing in the future. The research finds that none of the households invest part of their income to develop the processing of brown sugar, due to their income which can only fulfill consumptions. The assets owned by the household are the building for brown sugar processing and sugar cane plantation.

Additionally, it is not possible for most households to save their income, because there is not enough left to save. Only 2 out of 30 are able to save up to IDR 210.000/month. Most of the households that process brown sugar only rely on it when they need money, they can simply refine sugar cane into brown sugar then sell it to wholesalers.

\subsubsection{Factors affecting the decision of the households in producing brown sugar}

The factors measured in this study are the number of raw materials, labour, price, the experience of farmers and household needs. 
Table 4. Factors Affecting the Decision of Households in Producing Brown Sugar

\begin{tabular}{clcccc}
\hline No & Production Factor & Affecting & Percentage (\%) & Non-Affecting & Percentage (\%) \\
\hline 1 & Number of raw materials & 30 & 100 & 0 & 0 \\
2 & Number of workers & 13 & 43 & 17 & 57 \\
3 & Brown Sugar Price & 23 & 23 & 23 & 77 \\
4 & Experience & 4 & 13 & 26 & 87 \\
5 & Household needs & 25 & 25 & 5 & 17 \\
\hline
\end{tabular}

From the table above, it can be seen that the factors that affect the decision of household to produce brown sugar are the amount of raw material and the price.

\subsubsection{Factors affecting household consumption}

The factors measured in this reseach are income, the number of family members, the number of family members who are still at school and education.

Table 5. Factors Affecting Household Consumption

\begin{tabular}{llcccc}
\hline No & \multicolumn{1}{c}{$\begin{array}{c}\text { Consumption } \\
\text { Factor }\end{array}$} & $\begin{array}{c}\text { Influence } \\
\text { (person) }\end{array}$ & $\begin{array}{c}\text { Percentage } \\
(\%)\end{array}$ & $\begin{array}{c}\text { Non- } \\
\text { Influence } \\
\text { (person) }\end{array}$ & $\begin{array}{c}\text { Percentage } \\
(\%)\end{array}$ \\
\hline 1 & Household Income & 20 & 67 & 10 & 33 \\
2 & Family Members & 24 & 80 & 6 & 20 \\
3 & Family members in & 25 & 83 & 5 & 17 \\
4 & school & 4 & 13 & 26 & 87 \\
\hline
\end{tabular}

Based on the table above, it can be seen that the factors that affecting the consumption of the households are household income, number of family members, and number of families who are still in school.

\section{Conclusion}

The general description of the economy of brown sugar processing households in Kenagarian Bukik Batabuah can be seen from the work time allocation, total household income, total household consumption, investment and household savings. The working time allocation on brown sugar processing is higher than other activities. Households spend more of their income on food consumption than non-food consumption. Additionally most of the household income are spent on consumption, so that there is not enough income left to invest and save.

The factors that affect the decision of households to produce brown sugar are the amount of raw material and the price. Meanwhile, the factors that affecing the consumption of households are income, number of family members, and number of family members who are still in school. 


\section{REFERENCES}

[1] R. Akzar, "Analisis Kelayakan Pengembangan Usaha Pengolahan Gula Merah Tebu Pada UD Julu Atia, Kecamatan Polongbangkeng Selatan, Kabupaten Takalar", Undergraduated Thesis, Faculty of Economics and Management, Institut Pertanian Bogor, Bogor, 2012.

[2] Dinas Kehutanan dan Perkebunan Kabupaten Agam, "Pedoman Umum untuk Pengembangan Tanaman Tebu", Kabupaten Agam, Sumatera Barat: Dinas Kehutanan dan Perkebunan Kabupaten Agam, 2013.

[3] Badan Pusat Statistik Sumatera Barat, "Kabupaten Agam dalam Angka", Sumatera Barat: Badan Pusat Statistik Sumatera Barat, 2015.

[4] F. Nadia, "Peranan Karakteristik Kewirausahaan Terhadap Serapan Kredit dan Pengembangan Usaha Pengolahan Gula Merah Tebu di Kabupaten Agam", Thesis, Universitas Andalas, Padang, 2017.

[5] F.A. Indah, "Faktor - Faktor yang Mempengaruhi Intensi Berwirausaha Petani Pengolah Gula Saka di Kabupaten Agam. Thesis, Universitas Andalas, Padang, 2017.

[6] Sugiyono, "Metode Penelitian Kuantitatif dan Kualitatif", Bandung: ALFABETA, 2011.

[7] M. Nazir, "Metodologi Penelitian". Bogor: Ghalia Indonesia, 2005. 